\title{
FLORIANI, Dimas e KNECHTEL, Maria do Rosário. Educação Ambiental, Epistemologia e Metodologias. Curitiba: Vicentina, 2003. 143p.
}

\author{
José Edmilson de SOUZA-LIMA*
}

Dimas Floriani fez o Doutorado na Bélgica (UCL) e o Pós-Doutoramento no México (El Colégio de México e PNUMA). É professor e pesquisador do Programa de Doutorado em Meio Ambiente e Desenvolvimento da UFPR, na linha de pesquisa de Epistemologia Ambiental. Além disso, é professor na graduação e no mestrado em sociologia (UFPR).

E Maria do Rosário Knechtel é Doutora em Sociologia da Educação (UfSM), concluiu o primeiro PósDoutoramento na Espanha (UNED) e o segundo na Alemanha, na Universidade Karlsruhe. É professora e pesquisadora do Programa de Doutorado em Meio Ambiente e Desenvolvimento (UFPR), na linha de pesquisa de Epistemologia Ambiental e coordenadora do Curso de Especialização em Educação, Meio Ambiente e Desenvolvimento (UFPR).

Os quadros de referências dos autores são Fritjof Capra, com sua visão unificadora; Edgar Morin, com seu paradigma da complexidade; Jean Piaget, com sua epistemologia genética ou construtivista; e Enrique Leff, com seu diálogo de saberes e a racionalidade ambiental. Além destes, ainda há espaço para Maturana e Varela; Sheldrake; Paulo Freire e Fourez.

O pressuposto central que sustenta toda abordagem do livro é a não separação entre natureza e sociedade. Emerge deste pressuposto um conjunto de novas pistas para se produzir e acessar conhecimentos envolvendo os domínios naturais e sociais.

Ao longo dos capítulos, são explicitadas e demonstradas várias experiências, consideradas marginais pelos saberes "lineares" ou "normais", que revelam a necessida- de de se elaborar novos modos de produção e acesso de conhecimentos.

Dentre os enfrentamentos presentes no livro, é possível destacar a epistemologia genética de Piaget, que centra sua análise no processo dialógico e recursivo de produção do sujeito e objeto. Note-se que, para Piaget, sujeito e objeto constroem-se mutuamente no processo de construção do conhecimento; não há a priori. A abordagem de Piaget é fundamental para a presente obra porque muito contribui para o debate da interdisciplinaridade.

A visão unificadora de Capra parte da premissa de que existe um nexo comum a todo e qualquer sistema vivo, a capacidade de se organizar em forma de rede. A partir daí, Capra avança para a conclusão de que não há diferença entre a natureza biológica, a natureza da mente e a natureza da sociedade, pois todos são sistemas autopoiéticos ou com metabolismo próprio. Se são idênticos nesta dimensão auto-organizadora, a abordagem sistêmica que ele propõe é fértil para todos os sistemas vivos. Está, portanto, estabelecida a visão unificadora dos sistemas vivos. Nas palavras do próprio Capra,

\footnotetext{
...para aplicar essa compreensão da natureza da vida à dimensão social do ser humano (...) precisamos tratar do pensamento conceitual, dos valores, do sentido e da finalidade - fenômenos que pertencem ao domínio da consciência e da cultura humanas. Isso significa que, antes de mais nada, precisamos incluir uma compreensão da mente e da consciência em nossa teoria dos sistemas vivos. (CAPRA, 2002, p. 48)
} 
Embora fértil, o arcabouço epistemológico apresentado por Capra contém algumas insuficiências, percebidas pelos autores.

Capra funciona como uma espécie de alter ego crítico do atual modelo explicativo sobre a natureza, a consciência cognitiva e as culturas humanas. Neste sentido, seus objetivos estão plenamente alcançados. Duvidamos porém de que o desenlace do real ocorra no sentido esperado por Capra, de que todos os sujeitos humanos possam dar-se conta do real da mesma maneira pela qual ele teve acesso ao mesmo e construiu suas estratégias cognitivas. (FLORIANI e KNECHTEL, 2003, p. 24)

Identificadas as insuficiências do modelo de Capra, os autores sugerem alguns reparos.

\begin{abstract}
A incorporação ao seu pensamento [o de Capra] do princípio da incerteza talvez pudesse funcionar como uma espécie de vigília epistemológica acerca dos prováveis caminhos a trilhar pela humanidade. Não nos esqueçamos de que a dimensão ética no ser humano é fundamental, pela qual este tenta corrigir possíveis erros de rota, mas por outro lado, o ser humano é um ser incompleto e, por definição, um sistema aberto em direção a um destino incerto e também aberto! (FLORIANI e KNECHTEL, 2003, p. 24)
\end{abstract}

O paradigma da complexidade de Edgar Morin pressupõe a aproximação radical entre natureza e sociedade sem que haja redução abusiva de um domínio sobre o outro. Evitando generalizações perversas no interior da teoria geral dos sistemas, Morin convida e incita a elaboração de novos modos de produção e acesso de conhecimentos ancorados na reforma do pensamento. Para ele, os novos saberes devem ser capazes de "corrigir desvios provocados por equívocos dos sistemas socioculturais que podem comprometer a continuidade da espécie humana e da própria vida planetária" (FLORIANI e KNECHTEL, 2003, p. 27).

A contribuição de Leff está contida em sua preocupação com o diálogo de saberes e com a racionalidade ambiental. Há de se notar que Leff não acredita nem aceita soluções para os problemas ambientais centradas na lógica colonizadora do mercado, orientada pela racionalidade instrumental. Ao contrário desta última, os saberes ambientais das comunidades em extinção são os pilares de uma outra racionalidade, a ambiental. Neste sentido, os saberes ambientais forçam os saberes disciplinares - que são insuficientes - a enfrentarem novas racionalidades, desta vez, socioambientais.

A partir destes principais marcos teóricos e epistemológicos, nos capítulos seguintes os autores abordam a educação ambiental, fundamentalmente, como estratégia integradora da natureza e da sociedade.

A partir da inseparabilidade entre natureza e sociedade, os autores combinam metodologias que captam complementaridades e antagonismos entre abordagens que se esforçam em aproximar natureza e sociedade sem hierarquia de um sobre o outro.

Os autores concluem o livro apresentando experiências interdisciplinares vivenciadas por ambos no programa de Doutorado em Meio ambiente e Desenvolvimento. Notese que é esta uma das melhores maneiras de se concluir uma pesquisa que enfrenta temas associados à complexidade, pois se há dificuldades de operacionalização em pesquisas lineares, nas aqui relatadas a dificuldade expandese de forma assustadora. Mas, a despeito dos obstáculos, a operacionalização de pesquisas a partir das teorias não-lineares é possível. É o que demonstraram os autores no presente livro.

O livro em si mesmo representa uma quebra paradigmática se considerar-se que a maioria dos cientistas da sociedade ainda resiste em se ocupar de temas "reservados" às ciências da natureza. A abertura das ciências sociais para os temas ambientais é um indicador do processo de "reencantamento" do mundo, revela as insuficiências dos saberes isolados e, além disso, a necessidade se caminhar em direção à incerteza ou à complexidade da vida. A Educação, ao incorporar o adjetivo "ambiental", enfrenta a complexidade porque obriga os educadores a se educarem junto com os educandos de forma recursiva ou reflexiva.

\section{A quem será útil o livro?}

A epistemólogos lineares que já começaram a perceber as insuficiências de seu modo de produção e acesso de conhecimento. A epistemólogos não-lineares para que se convençam acerca do valor afirmativo da marginalidade ou da ética da transgressão, sugerida por Nietzsche. A educadores dispostos a enfrentar a incerteza como possibilidade emancipatória tanto para si mesmo quanto para seus educandos. E, finalmente, ao público em geral que já tenha 
se dado conta de que um outro mundo é possível e a educa-

\section{REFERÊNCIAS}

CAPRA, F. As conexões ocultas: ciências para uma vida sustentável. São Paulo: Cultrix, 2002. ção ambiental emerge como uma das possibilidades civilizatórias. 